\title{
Prospects of Nuclear Power Today as Part of Ghana Energy Mix and Socio-Economic Development
}

\author{
S.A. Birikorang1, J. K. Gbadago ${ }^{2}$, E. H. K. Akaho², B.J.B. Nyarko ${ }^{2}$, \\ E.Ampomah-Amoako ${ }^{1}$, H. C. Odoi ${ }^{1}$, R.G. Abrefah ${ }^{1 *}$, S. K. Debrah ${ }^{1}$, \\ R.B.M. Sogbgaji ${ }^{1}$, E. Boafo ${ }^{1}$ and J. Boffie ${ }^{1}$ \\ ${ }^{I}$ Department of Nuclear Engineering \& Material Science, School of Nuclear and Allied Sciences (SNAS), \\ University of Ghana, Accra-Ghana. \\ ${ }^{b}$ Ghana Atomic Energy Commission, Accra-Ghana. \\ crossref $\mathrm{http}: / / \mathrm{dx}$.doi.org/10.5755/j01.erem.60.2.1109
}

(received in January, 2012, accepted in June, 2012)

\begin{abstract}
Energy is absolutely essential for the economic development and improvement of the quality of life in every human settlement. Considering her economic aspirations and population growth, Ghana's energy demand, particularly that for electricity, is sure to rise in coming years. Currently Ghana's total installed electricity generation capacity stands at $1810 \mathrm{MW}$, with her population estimated to be 24.4 million, based on the 2010 census. The country is confronted with a challenge of meeting her energy needs in a cost effective and environmentally friendly manner so as to attain the middle income status. This policy document presents the nuclear power as a most versatile, convenient and competitive source of electrical energy that should be planned for the present and will be worth introducing into Ghana's energy mix for sustainable development of the country. Nuclear Power Plants can serve as a competitive source of electrical energy for enhancing Ghana's energy security and her socio-economic development to attain middle income as purported by political policies.
\end{abstract}

\section{Introduction}

\subsection{Ghana's economy and demography}

Ghana's current population is estimated to be 24.4 million based on the 2010 census. The economy of Ghana is agriculture with a GDP per capita of about $\$ 700$ and purchasing power parity (ppp) of $\$ 3000$. Agriculture constitutes about 36\% of GDP. To arrest the current situation, the Ghana government has launched a program to propel Ghana's economy to a middle-income status by 2020 .

The total installed electricity capacity generation in Ghana currently stands at $1810 \mathrm{MW}$. This is made up of Hydro Power with power-installed capacity of
1180MW and Thermal Power of 630MW. Ghana's Electricity generation is growing by 7 percent per annum. This growth rate is expected to increase, if the government plan to achieve a middle-income status by 2020 is kept on track. High dependence on rain-fed Hydro Power, which accounts for 65 percent of installed capacity, has led to short falls in electricity supply in the case of drought. Due to the latter, in 2006 and 2007 the nation experienced its third and worst major energy crisis.

Thermal plants are currently run on light crude oil imported from Nigeria. Efforts are taken to run the plants on gas imported from Nigeria through the West African Pipeline. At the present time there are delays 
in the supply of gas from Nigeria. The Nigerian Minister of State for Petroleum Resources admits that the ongoing crisis in the turbulent Niger Delta Region of the country may delay the supply of natural gas to Benin, Togo and Ghana through the West African Gas Pipeline (WAGP),

(see http://www.bicusa.org/en/Article.2940.aspx).

The energy security of Ghana is under threat due to uncertainties over the future gas supply from Nigeria as a result of frequent crises in the Niger Delta. Another reason is Nigeria's own growing demand with an increasing number of thermal power plants to be constructed. The suggested NigerianAlgerian Gas Pipeline through the Sahara Desert to export gas to Western Europe is also a major problem to consider. The energy crisis in Ghana compelled the then Energy Minister K.T Hammond in 2006 to say, "Ghana's energy crisis began last August and continues to day with estimates that it could cost the country economy millions of dollars" (see http://news.bbc.co.uk/2/hi/africa/6692605.stm).

\subsection{Other energy options under consideration}

Medium hydropower projects at the Pwaluguon White Volta, the Jualeon Oti River, the Hemangon Pra River and those on the Ankobra and the Tano are estimated to provide a total installed capacity of 425MW. Contributions from renewable energy sources such as solar, wind, biomass are expected to produce 380-500 MW peak of electric power. This amount cannot exceed 10 percent of the required total demand. To foster political and economic cooperation in the West African sub-region, the West African power pool was launched in October 2000. This involves the interconnection of the national grids of 15 West African States across the distance of 5600 $\mathrm{km}$.

\subsection{Electricity Demand and Supply System}

The government recognizes that the availability of cheap and reliable supply of electricity is very critical to the realization of its macro-economic goals and improvement in the standard of living of its citizenry. The growth rate in electricity consumption over the last two decades (i.e. 1990 - 2009) was estimated at 3.0 percent per annum, which is less than half of 7.42 percent for the previous two decades $(1970-1990)$. The lower growth rate in electricity consumption was due to drastic shortfalls in hydropower generation because of severe droughts. The country therefore had to start importing electricity from neighbouring Cote d'Ivoire in 1994. In addition, from 1997 - 1999 and 2000 - 2001, the government constructed a $330 \mathrm{MW}$ and 220 Thermal Power Plants based on light crude oil to unravel the situation. These efforts were attempts to diversify electricity generation from dependency on hydropower systems, which had accounted for about 99.0 percent of the generation mix in 1995 . In recent years, the very high prices of light crude oil have made electricity generation from these thermal power plants very expensive warranting increases in electricity tariffs, a threat to increased economic activity and improvement in standard of living. The government therefore sought to import a cheaper natural gas from Nigeria as an alternative to light crude oil. However, has now become a major problem due to the ongoing crisis in the Nigeria's turbulent Niger Delta Region. Fig. 1 shows the projected energy demand of Ghana from now to 2030.

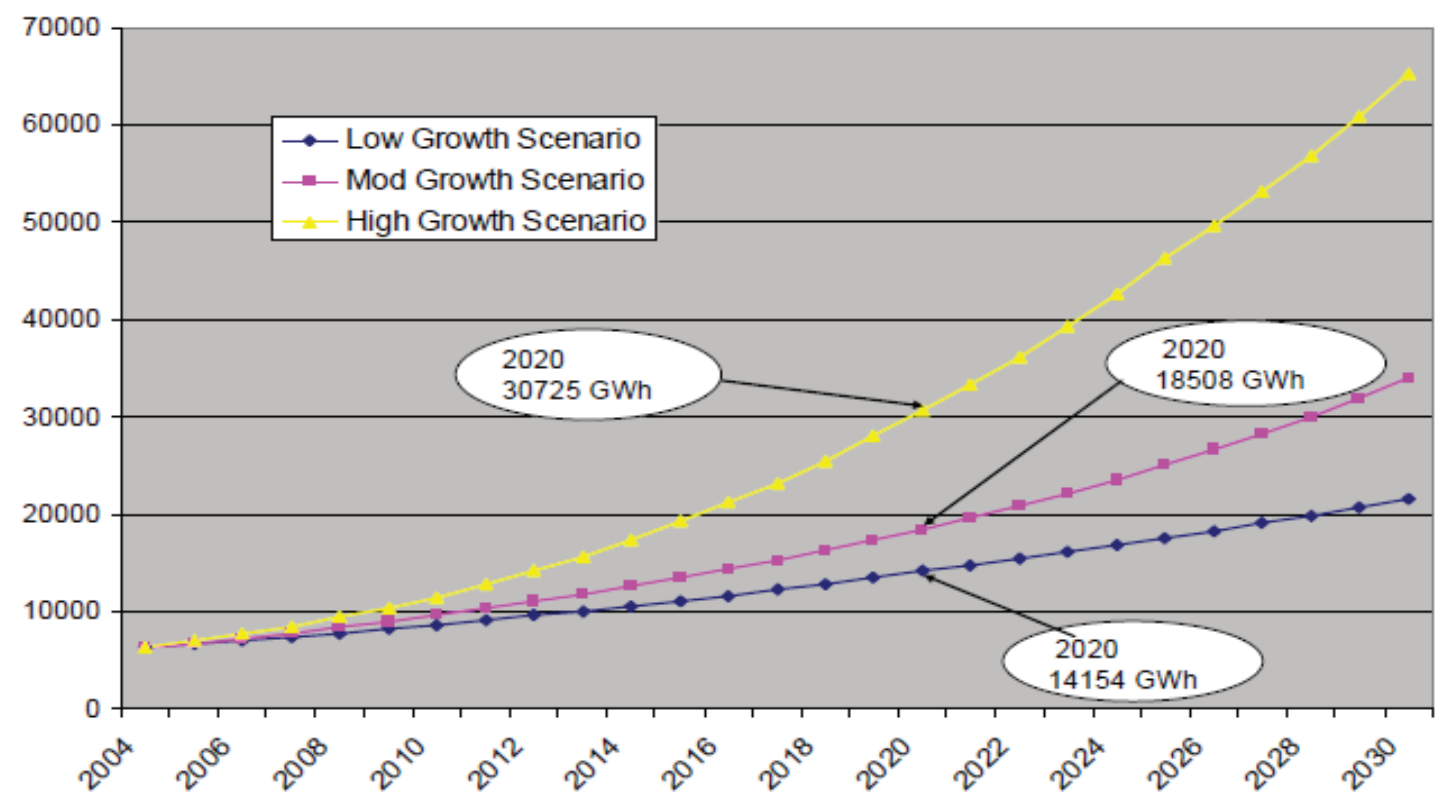

Fig.1.

Projected electricity demand using MAED model 


\subsection{Nuclear Power Option}

In 2007 when the third major energy crisis occurred, difficulties to raise funds to procure light crude oil for thermal power generation to meet the shortfall in the face of high crude oil prices and delays in the West African Gas pipeline project brought the consideration of nuclear energy for electricity generation to the fore. The President of Ghana set up a committee to assess the viability of the nuclear option in Ghana. The government later on took a cabinet decision to build a $400 \mathrm{MW}$ nuclear power plant by 2018 following the submission of the committee's report to the President. Current Energy crisis in Ghana is posing major threat to its economic growth. The scenario demands for a radical change in energy mix. While securing cheap and reliable energy resource to quench the thirst of future industrial endeavours, it is the need of hour to explore the unconditional means.

In this regard, nuclear energy is a descent choice without compromising environmental quality. It would be worth mentioning here that the whole cycle of nuclear power generation (from mining of ore to construction and electricity generation followed by spent fuel storage, reprocessing, waste disposal and finally decommissioning) produces only about 2.5 5.7 $\mathrm{gC}_{\mathrm{eq}} / \mathrm{kwh}$ (grams of carbon equivalent in term of share to produce green house gases per kilowatt hour electricity production) as compared to 105-366 $\mathrm{gC}_{\mathrm{eq}} / \mathrm{kwh}$ for that of fossil fuel and 2.5-7.6 $\mathrm{gC}_{\mathrm{eq}} / \mathrm{kwh}$ from renewable energy resources such as water and wind.

\subsection{Human Capability}

Taking into account Ghana's capabilities in the field of nuclear engineering, training of human resource by GAEC and IAEA at the School of Nuclear and Allied Sciences and relevant available infrastructure, nuclear energy could be a viable solution. More importantly, Ghana owns a $30 \mathrm{~kW}$ Chinese-built tank-in-pool research reactor that was commissioned on 15th March 1995 (Akaho et al. 1995) and still operating. The reactor is cooled and moderated with light water. Light water and beryllium are used as reflectors. It is mainly used for Neutron Activation Analysis, production of short-lived radioisotopes, education and training. The reactor is operated by the National Nuclear Research Institute under the Ghana Atomic Energy Commission (E. Ampomah-Amoako et al. 2011). With the expertises and the training of human resource from the commission, the government of Ghana was well convinced when the committee sent the report.

In Ghana, under the Atomic Energy Commission, research, development and utilization of nuclear energy are carried on only for peaceful purposes. The commission do this with assurance of safety, democratic and autonomous operation, publicizing the results, and actively contributing to the international cooperation. Sustaining this principle, it is aimed to secure energy resources in the future, to achieve the progress in science and technology and in promotion of industries, and thereby contribute to the welfare of mankind and to the elevation of national standards of living.

\subsection{Public Views on Nuclear}

Table 1 shows the views of some selected people from various Universities and some workers in Ghana about the introduction of nuclear energy to the Ghana energy mix. Results show that most people in Ghana are in favour of the introduction of nuclear energy because of the energy situation facing the country. Some even said the situation is getting worse since the beginning of this year, 2012 that has almost blackout every day. Those who are against of the introduction need are frightens because they see it to be very dangerous. They also have problem with the maintenance culture of the country and the rising global concern over countering global warming. Public education on nuclear policy is what they recommended.

Table 1. Opinion of Pull Survey from some selected university students and workers

\begin{tabular}{||l|l|l||}
\hline \hline Age Group & In favour (\%) & Against (\%) \\
\hline 50 and above & 53 & 47 \\
\hline $49-30$ & 59 & 41 \\
\hline $29-18$ & 69 & 31 \\
\hline
\end{tabular}

History and general description of nuclear power operation, global interest and types of nuclear power plant are presented in the next section. This will provide Ghana with possibilities of considering the type of a nuclear reactor suitable for her economic development.

\section{General description of nuclear power}

\subsection{Nuclear power and global interest}

Nuclear power is any nuclear technology designed to extract usable energy from atomic nuclei via controlled nuclear reactions. The most common method today is through nuclear fission, though other methods include nuclear fusion and radioactive decay by the use of nuclear reactors or other nuclear facilities. A nuclear reactor is a device in which nuclear fission chain reactions are initiated, controlled, and sustained in a steady rate condition. The basic principle of nuclear fission reactor is that the reactor is used to convert energy into heat (Glasstone S, Sesonske A. 1994). 


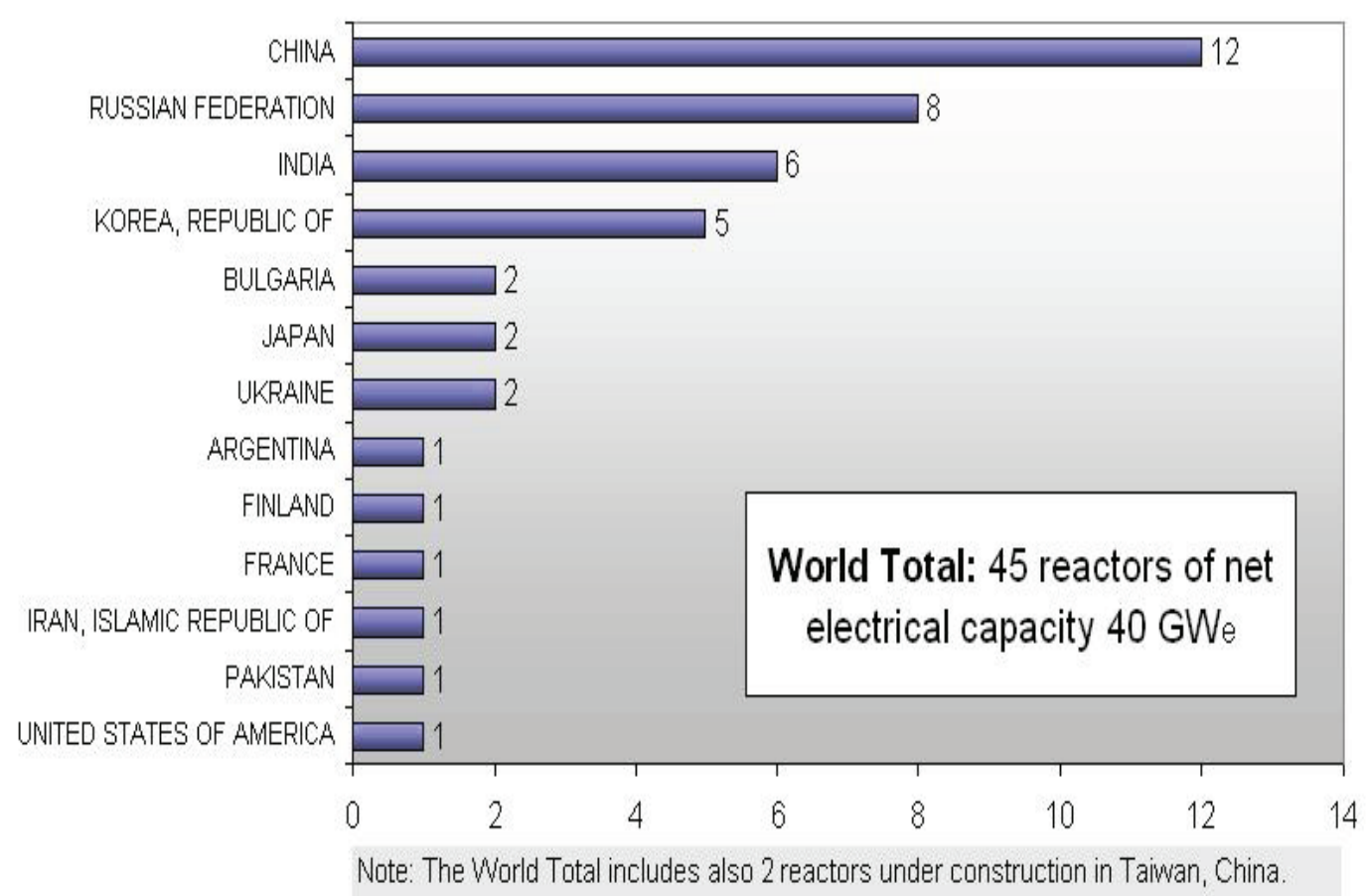

Fig.2.

45 more nuclear power plants are currently under construction

Nuclear reactors have been producing electricity since the 1950s and, as of March 2008, there are 436 nuclear reactors operating in 30 countries, while 45 more are under construction. The reactors depend on a reaction between neutrons and the atomic nuclei of the fuel for their operation. Uranium is the fuel for almost all reactors and consists principally of two isotopes: uranium-235 and uranium-238.
The fuel is assembled in an array called the core, which contains the moderator, which is a material (generally water or graphite) that slows or thermalizes the neutrons population. A coolant, usually water or gas, conducts heat away from the fuel and then passes through heat exchangers to make steam (J. R. Lamarsh and A. J. Baratta 1982).

Low Pressure

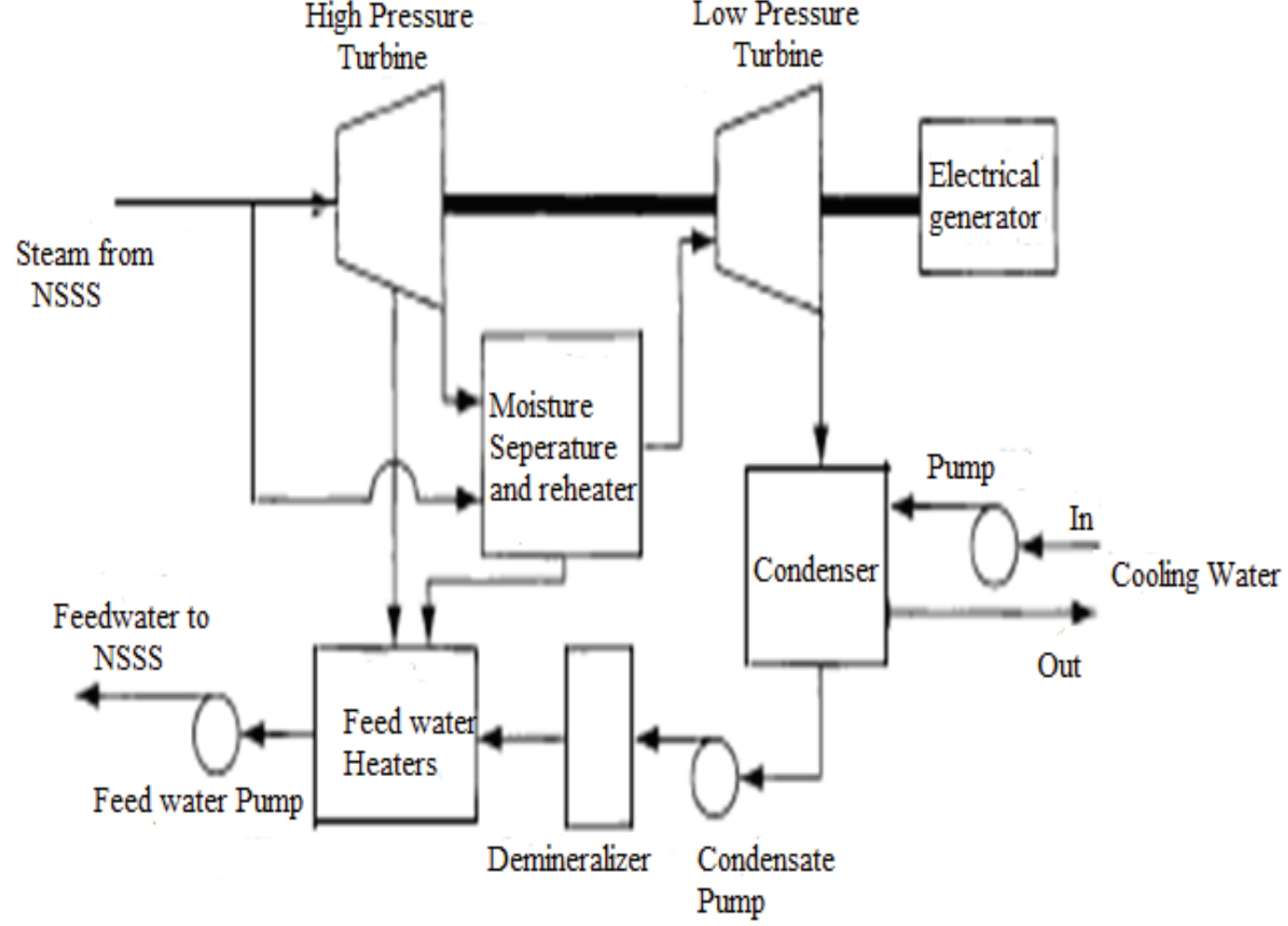

Fig.3. A simplified block diagram of a power-producing part of a nuclear steam power plant 
The energy released in the fission process generates heat, some of which is converted into usable energy. A common method of harnessing this thermal energy is to use it to boil water to produce pressurized steam, which will then drive the steam turbine that generates electricity (The Nuclear Tourist 2008). The fuel is sealed in metal containers, and the core is contained in a pressure vessel. Massive concrete shielding helps absorb the intense radiation emitted by the core during and after the operation. Most reactors also have an additional containment building surrounding the reactors and usually heat exchangers.

The diagram below shows a typical nuclear power reactor (i.e. the Canadian CANDU type) and its components.

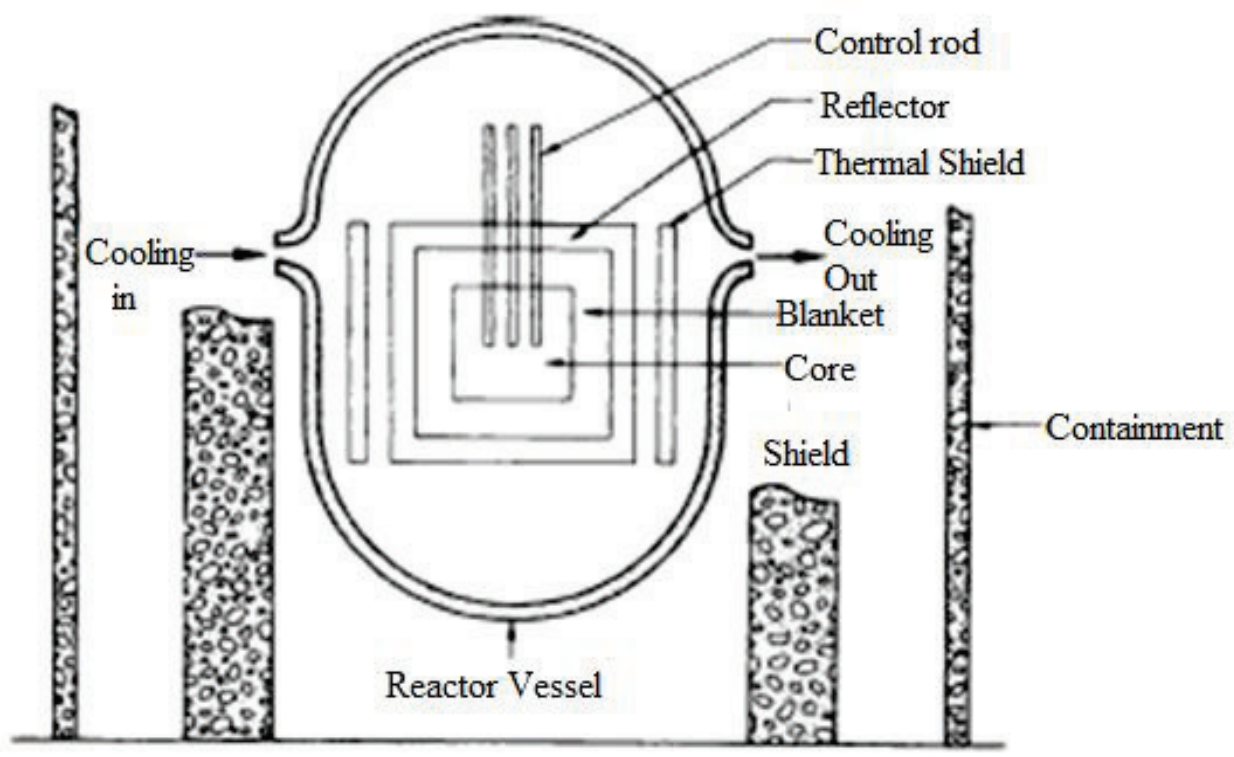

Fig.4. A schematic drawing of principal components of a nuclear reactor with radiation shield and containment

In the $1950 \mathrm{~s}$, attention turned to the peaceful purposes of nuclear fission, notably for power generation. Today the world produces as much electricity from nuclear energy as it did from all sources combined in 1960. Civil nuclear power can now boast over 14,000 reactor years of experience and supplies almost 14 percent of global electricity needs from the reactors in 30 countries. In fact, many more than 30 countries use nuclear-generated power. Many countries have also built research reactors to provide a source of neutron beams for scientific research and production of medical and industrial isotopes. With the operation of Ghana Research Reactor since 1995, Ghana's capability of operating nuclear power is in safe hands, since she has competent personnel, training human resource at the newly constructed Graduate School of Nuclear and Allied Science in collaboration of the International Atomic Energy Commission, the Ghana Atomic Energy Commission and the University of Ghana.

\subsection{Main types of nuclear reactors}

There are several types of nuclear reactors operating around the globe. Their main types are:

- Pressurized Water Reactors (PWRs), Boiling Water Reactors (BWRs), and Water

- Water Energy Reactor (WWER). The latter is a Soviet reactor design similar to a PWR. All of the above mentioned reactors use water as moderator and coolant. They can also be termed as Light Water Reactors.

- Heavy water reactors, such as the Canadiandesigned CANDU, use

- heavy water (water in which the hydrogen atoms have been replaced with deuterium, an isotope of hydrogen) as moderator and coolant.

- Gas cooled reactors use carbon dioxide gas as coolant and usually graphite

- $\quad$ as moderator.

- Water-cooled graphite-moderated reactors of the RBMK design are originally developed in the USSR (many of them are closed).

\section{The global concern}

\subsection{Nuclear energy contribution to solving social issues}

Nuclear power generation throughout the world is extremely varied. The use of nuclear power has been concentrated in industrialized countries. In 30 countries that possess nuclear power generation capacity, the percentage of electricity coming from nuclear reactors ranges from 78 percent in France to just 2 percent in China (The Role of Nuclear Power in Europe 2007). 


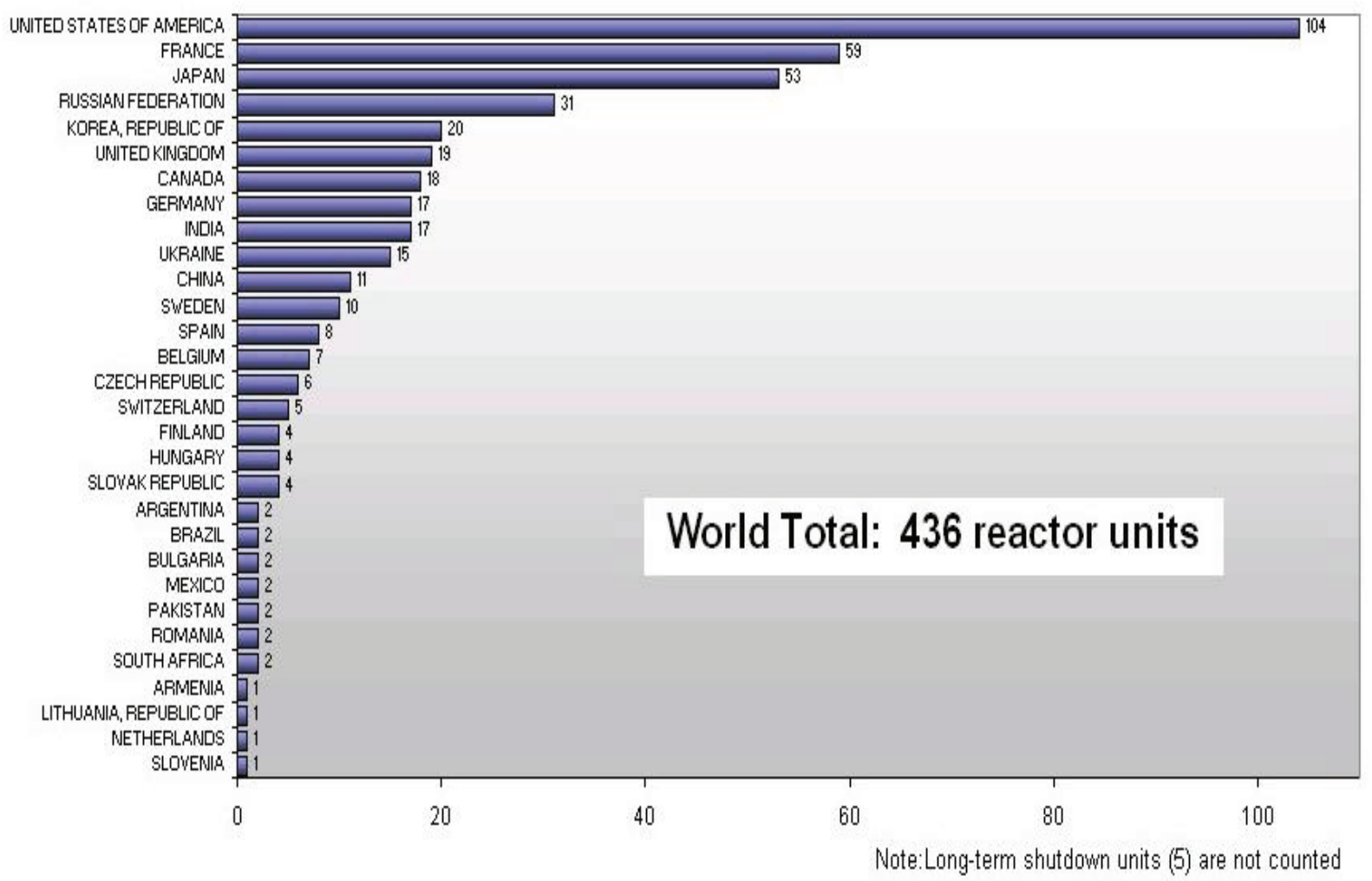

Fig.5. Number of globally operating nuclear reactors

Resurgence of interest in nuclear power is not limited to Asia and Europe alone, Africa joins them. Nigeria has initiated moves to construct 4 nuclear power plants. Ghana has been operating a nuclear research reactor for neutron activation analysis and human resource development since March 1995, and showing interest in the move for nuclear power. There is more and more talk about nuclear power generation, often in relation to wider issues, such as global warming and climate change. This renewed attention is encouraging public debates on the pros and cons of this technology involving media, politicians, and the public alike. Ghana has initiated the process to introduce nuclear power technology into her grid.

\subsection{Global warming countermeasures and nuclear power generation}

Nuclear power generation has very low emissions of carbon dioxide, which is greenhouse gas, compared to power generation using coal, petroleum, natural gas, etc., thus realizing large-scale power generation with better fuel economy. For this reason, in order to realize sustainable growth while reducing greenhouse gas emissions, it is a shared understanding in the international community that the utilization of nuclear power is indispensable (White Paper on Nuclear Energy JAE March 2010).

\section{The reasons for renewed interest of Ghana in NPP}

There are several reasons why Ghana has decided to grip hold of the chain of producing electrical energy using nuclear reactors as seen throughout the globe. Here are some few reasons:

\subsection{Energy diversity and energy security for development}

Since the central goal of sustainable development is to maintain or increase the overall assets available to Ghana, the development of nuclear energy will broaden the natural base for energy production. For many countries, nuclear power is a way to enhance the security and diversity of their energy supplies. This was also true in the 1970s, when concerns about energy security were triggered by disruptions in oil supply, which was a major cause of nuclear expansion in the countries such as France and Japan.

Nowadays the demand for electrical energy in Ghana is growing at the rate of 6 percent, and it has been estimated that by the year 2020 the energy demand will rise from the current $1200 \mathrm{MWe}$ to 3630MWe. However, the projected energy available from hydro sources, which is now the major electrical energy-generating source, will be 2400MWe indicating that there will be a shortfall of $1200 \mathrm{MWe}$. Since the rise in the cost of fossil fuel is subject to world political and economic fluctuations, wind, solar, and biomass may not be able to solve our energy problem. Hence, it will not be advisable for Ghana as a developing country to rely solely on fossil 
fuel import and conventional renewable energy sources. Thus, Ghana will need a mixture of energy technologies to ensure her energy security (Acquah I. 2007)

\subsection{Stable and low cost of nuclear fuel and economic competitiveness}

Nuclear fuel prices are low and stable. This is because nuclear power plants require low fuel supply; also, the nuclear fuel can be stock piled up to 10 years. It can significantly reduce the risks associated with fuel supply and price instability. The supply of nuclear fuel is not a problem, since there are several nuclear fabrication establishments. Nuclear fuels unlike oil or gas are only used to fuel nuclear reactors and nothing else (The Role of Nuclear Power in Europe 2007).

\subsubsection{Nuclear fuel cycle}

Procurement, preparation, utilization, and ultimate disposition of the fuel for a reactor are called a reactor fuel cycle. Those parts of the fuel cycle that precede the use of the fuel in a reactor are collectively called the front end of the fuel cycle. That portion related to the fuel after it has been withdrawn from a reactor is called the back end of the fuel cycle. Figure 5 shows the once-through fuel cycle for a PWR plant (J. R. Lamarsh and A. J. Baratta 1982).

Nuclear power is economically competitive over other energy sources for the countries, which have little or no indigenous fossil fuel reserves. This suits to France, Japan, South Korea, etc. The new breeds of nuclear power plants have extended lifetime of up to 60 years. Even though the capital cost of a nuclear power plant is initially high, the low cost of nuclear fuel and the extended lifetime make nuclear power cost effective and competitive. In addition, if current prices of fossil fuels continue to increase, the advantage of nuclear fuel will make nuclear energy even more competitive. Moreover, the development of small and medium size nuclear power plants (100$600 \mathrm{MWe}$ ) is aimed at cutting down the costs.

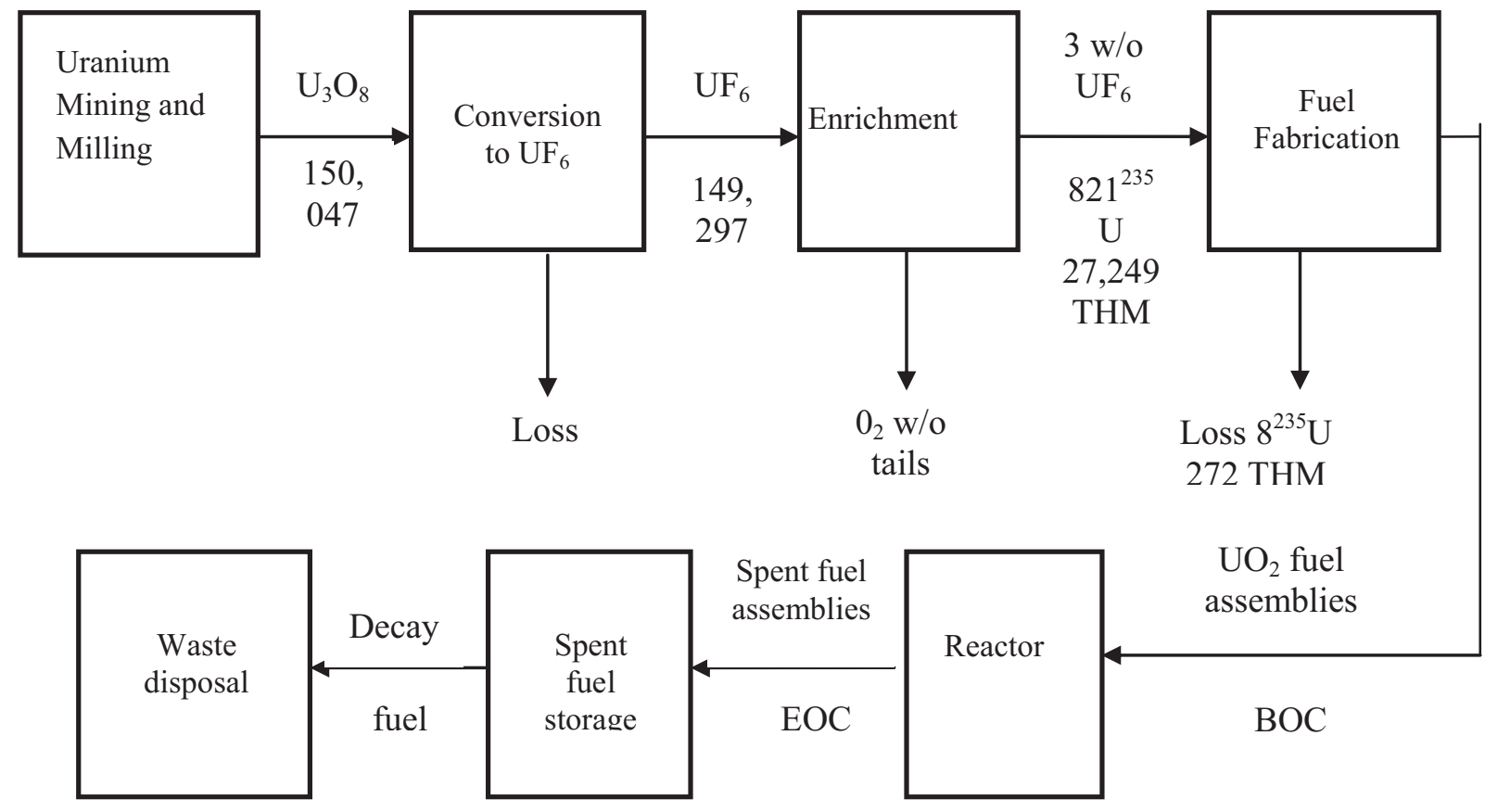

Fig.6.

LWR once-through fuel cycle

\subsection{Environmental concerns and performance}

Another driving factor for Nuclear Power which has aroused an interest of the country is the negligible or almost no emission of greenhouse gases (GHG). The complete nuclear power chain - from mining of uranium ore to manufacturing of fuel, to constructing and operating the reactor, and disposing of the waste - emits only 1.6 grams of carbon equivalent per $\mathrm{kW} / \mathrm{h}$. This is about the same negligible emission rate as that caused by wind and hydropower compared to coal, oil, and natural gas. Given its low emissions, nuclear power is seen by many as part of the solution to meet, for example, the new environmental constraints, like entry-into-force of the Kyoto protocol, and the 2007 G8 summit goal of cutting global emissions in half by 2050 .

Nuclear power is a mature technology with more than half a century of operating experience. The past two decades have seen significant improvements in nuclear power plant reliability, as well as lower operating costs, and a progressively improved safety record. 


\subsection{Ghana energy situation at present and her needs}

Ghana's energy consumption is estimated at 6.6 million tons of oil equivalents (TOE), and per capita energy consumption is estimated at 360 kilograms of oil equivalent (KOE). The majority of Ghana's energy use is from biomass in the form of firewood and charcoal. These two account for about 59 percentage of the total energy consumption. Petroleum products and electricity constitute 32 percent and 9 percent, respectively.

Traditional fuels such as firewood and charcoal provide the bulk of energy needs followed by petroleum and then electricity. It is estimated that about 84 percent of households in rural Ghana use fuel-wood in its untransformed state as their source of fuel. A further 13 percentage depend on charcoal as their fuel of choice for cooking. All other sources, for example, electricity, kerosene and LPG together account for less than 3percentage of consumption and are therefore relatively insignificant.

Electricity and kerosene are the main sources of energy for lighting in Ghana. About 60 percent of all households in the country (both urban and rural) still use kerosene for lighting, while 39 percent of households use grid-connected electricity for lighting. In the rural areas, as much as 82 percent of households still use kerosene, candles, and other traditional fuels as sources of light. In addition, 17.1percent of rural households obtain their lighting from grid-connected electricity (Wiafe K. 2005).

\section{Future needs and electricity expansion plan in Ghana}

Energy is essential for development of the country. Nearly every aspect of development - from reducing poverty and raising living standards to improving health care, industrial, and agricultural productivity - requires reliable access to modern energy sources. In this context, it is important for Ghana to plan for the future and expand her energy mix considering the global lack of access to electricity. As such, energy will continue to be an important part of the global agenda for the near future. This country can ensure adequate benefits from the technology by pursuing the process of its introduction.

As far as the electricity expansion plan in Ghana concerns, it is a fact that the hydro electricity potential and the Bui hydro project underway are very limited and will be relatively expensive to exploit. The look at the country from the point of construction of the West African Gas Pipeline (WAGP) is also somehow constrained. The natural gas supply through the West African Gas Pipeline (WAGP) could reduce the reliability of the power system, for both the source and the pipeline system have suffered disruptions not long ago through either marine accidents or sabotage.
In the midst of all these uncertainties, nuclear power could provide the energy deficit to the required capacity by 2020 and with almost unlimited technical possibilities for further expansion. Nuclear energy is a clean form of energy production, since it does not produce any sulphur dioxide gas $\left(\mathrm{SO}_{2}\right)$, particulates, oxides of nitrogen $\left(\mathrm{NO}_{\mathrm{X}}\right)$, volatile organic compounds (VOCs), or greenhouse gases unlike the fossil fuel sources (Akaho E.H.K. 2008).

\section{Public concerns about the national idea on nuclear power}

There are many public concerns about Ghana ideas of adding nuclear power to her energy mix ranging from a whole lot. Some of the public concerns are about its safety issue, waste management way to human resource expertises.

\subsection{Nuclear safety concern}

On the question of safety, the record of nuclear power plants is the best. There have been only two major accidents for the past 20 years (Three Mile Island 1979, and Chernobyl 1986). There were no fatalities at the Three Mile Island. The latter caused 31 fatalities compared to the single Bhopal disaster (from Chemical plant), which claimed 3000 lives. There has been very significant improvement in plant safety in the nuclear industry worldwide. Countries which suspended their nuclear programs as a result of the Three Mile Island and the Chernobyl accidents have stated to be reactivating them. President Bush Administration energy plan released in May 2001 stated that nuclear energy is an essential part of the nation energy mix, and directed the Department of Energy to support the expansion of nuclear power generation in the United States as 'a major component of national energy policy'(http://ww.iaea.org/Publications/Booklets/Nucl ear Power/np08.pdf).

\subsection{Nuclear waste (spent fuel)}

The waste associated with nuclear power plants is small in volume, well confined, and highly monitored, unlike the solid and toxic wastes produced by other fuel chains. Also ultimate disposal methods of nuclear waste are well known. The major waste from nuclear power plants is the spent fuel. The spent fuel can be reprocessed for fuelling future nuclear plants. The contract agreement with the suppliers of the nuclear power plant will include a clause, which will require the spent fuel to be shipped back to their home country. The spent fuel, however, can be safely stored for decades at the reactor and interim storage sites before shipment to the supplier. In this regard, agreement with suppliers of reactors will include a 
clause, which will require the spent fuel to be shipped back.

\subsection{Local expertise}

Ghana has the capacity and the ability to manage an advanced and high technology without any problems to worry about. Since 1995, the Ghana Atomic Energy Commission has been operating a 30kilowatt research reactor (GHARR-1) at Kwabenya. Solely, well-trained Ghanaian personnel manage the research reactor; and the safety record of GHARR-1 according to the International Atomic Energy Agency (IAEA) is very good. Safety against nuclear proliferation has been taken care of by the Government of Ghana, since she has signed and ratified the Non- Proliferation Treaty (NPT) and other Safeguard Protocols (Akaho E.H.K. 2000).

\section{Recommendation}

Since public acceptance plays a crucial role in the success of a nuclear power program, the necessary public education should be embarked upon, so as to allay public fears and anxieties about the safe and beneficial use of nuclear power as a viable alternative source of electricity in Ghana. The Ghana Atomic Energy Commission must enhance their publicity on nuclear policy in Ghana so that her people become knowledgeable and have an increased interest in this type of energy.

\section{Conclusions}

The energy situation of Ghana is under serious threat. It is due to the growth of population, difficulties in raising funds to procure light crude oil for thermal power generation to meet the shortfall in the face of high crude oil prices and uncertainties over the future gas supply from Nigeria. Hereby, to attain the middle-income status by 2020 as promised, the energy situation must be critically ascertained. The projected electricity demand using the MAED Model shows that Ghana is seriously in need of energy considering the growth rate.
This Executive Summary presents the facts on viability of the nuclear option and the necessary implementation steps for nuclear power generation in Ghana. Based on the economic, safety, and environmental advantages of nuclear power and the availability of proven technologies of managing the nuclear waste, the Government of Ghana welcomes the introduction of nuclear power to the energy mix of Ghana. This is to ensure economic power supply in an environmentally friendly manner and also to enhance national energy security for sustainable national development of the country. In conclusion, the prospect of nuclear power today for the socioeconomic development of Ghana is an outstanding decision taking by the country.

\section{References}

Acquah I, Nuclear for Ghana's Development, 2007.

Akaho, E. H. K., Nuclear Power for Generating Electricity in Ghana: The Issues and Challenges, Ghana Academy of Arts and Sciences, 2008.

Akaho E.H.K, S. Anim-Sampong, D. N. A. DodooAmoo, B. T. Makuu, G. Emi-Reynolds, E. K. Osae, H.O. Boadu and S. Akoto-Bamford, Final Safety Analysis Report for Ghana Research Reactor-1, GAEC-NNRI-RT-90, 2000.

E. Ampomah-Amoako, "Environmental and Safety Concerns for Nuclear Power Generation in Ghana', Environmental Research, Engineering and Management, 2011. No.1(55), P. 49-65

Glasstone S, Sesonske A, Nuclear Reactor Engineering-Reactor Design Basics, Fourth Edition, Volume 1, 1994.

International Atomic Energy Agency, International Status and Prospects of Nuclear Power, IAEA, Vienna, 2008,

http://ww.iaea.org/Publications/Booklets/Nuclear Power/np08.pdf

Lamarsh J. R, Baratta A. J, Introduction to Nuclear Engineering, Third Edition, November 1982

The Nuclear Tourist. Reactor Protection \& Engineered Safety Feature Systems". Retrieved on September 25, 2008.

The Role of Nuclear Power in Europe, 2007 World Energy Council

http://www.bicusa.org/en/Article.2940.aspx

White Paper on Nuclear Energy, Japan Atomic

Energy Commission, Cabinet Office, March 2010

Wiafe K, Development and Energy in Africa-Ghana Country Report, September 2005. 
Patirtis, apžvalgos, diskusijos

\title{
Atominės energetikos perspektyvos ir socioekonominė plėtra Ganoje
}

\author{
S.A. Birikorang ${ }^{1 *}$, J. K. Gbadago ${ }^{2}$, E. H. K. Akaho ${ }^{2}$, B.J.B. Nyarko ${ }^{2}$, \\ E. Ampomah-Amoako ${ }^{*}$, H. C. Odoi ${ }^{1^{*}}$, R.G. Abrefah ${ }^{* *}$, S. K. Debrah ${ }^{1^{*}}$, \\ R.B.M. Sogbgaji ${ }^{1^{*}}$, E. Boafo ${ }^{1^{*}}$, J. Boffie $^{1^{*}}$ \\ ${ }^{1}$ Ganos universitetas, Gana \\ ${ }^{2}$ Ganos atominès energetikos komisija
}

(gauta 2012 m. sausio mèn., priimta spaudai 2012m. birželio mèn.)

Remiantis $2010 \mathrm{~m}$. duomenimis, Ganos elektros energijos gamybos pajègumas - $1810 \mathrm{MW}$; tai tenka 24,4 milijonų vartotojų. Planuojama, kad artimiausioje ateityje dèl ekonominès plètros ir žmonių skaičiaus didèjimo augs energijos, ypač elektros energijos, poreikis. Todèl būtina tenkinti kylanti energijos poreiki, atsižvelgiant i esamas gyventojų pajamas ir aplinkosauginius reikalavimus. Straipsnyje pateikiama analizè ir gauti rezultatai dèl tinkamiausių Ganos tiekiamos energijos šaltinių remiantis darniosios plètros principais. Teigiama, kad atominès elektrinès leistų užtikrinti Ganos energetini saugumą ir patenkintų socioekonominès plètros poreikius. 